\title{
Comparison in Wrist Splints and Wrist-Metacarpophalangeal Splints Use for Patients with Carpal Tunnel Syndrome
}

\author{
Evi Yuliani ${ }^{1}$, Widjajalaksmi Kusumaningsih, Vitriana ${ }^{2}$, Hadyana Sukandar ${ }^{3}$ \\ ${ }^{1}$ Department of Physical Medicine and Rehabilitation, Cipto Mangunkusumo Hospital, Jakarta \\ 2 Department of Physical Medicine and Rehabilitation Hasan Sadikin Hospital Bandung \\ 3 Post Graduate Programme Faculty of Medicine University of Padjajaran, Bandung
}

\begin{abstract}
Objectives : To compare the effect of both wrist splint and wrist-metacarpophalangeal splint at night using Symptom Severity Scale (SSS) and Functional Status Scale (FSS) and to know the validity and reliability of Indonesian version of SSS dan FSS.

Methods : This study enrolled 19 subjects in each of the two groups that were given neutral wrist splint and exercise in one group (group A) and neutral wrist-metacarpophalangeal splint and exercise in the other group (group B).

Results : Indonesian version of SSS and FSS have been proven valid with rs lowest $=0.360$ and highest $0.810(>0.3)$ and reliable with $\alpha \mathrm{SSS}=0.762$ dan FSS $=0,781(>0.7)$. There were significant improvement score of SSS and FSS in each group with $p$ value $<0.001$. There were greater functional improvement in group treated with wrist-metacarpophalangeal splint (group B) with $\mathrm{p}$ value $=0.036$ $(\mathrm{p}<0.05)$.
\end{abstract}

Conclusions: There was improvement of SSS and FSS in both groups of study with greater improvement of in wrist-hand splint group.

Keywords: Carpal Tunnel Syndrome, wrist splint, wrist-hand splint,,nerve and tendon gliding, SSS, FSS.

\section{INTRODUCTION}

Use of wrist splint is a part of the nonpharmacologic management for Carpal Tunnel Syndrome (CTS) in Physical Medicine and rehabilitation. CTS is a group of signs and symptoms of neuropathy due to accumulative repetitive injury that entraps the median nerve passing wrist area.

Received in March 2012 and accepted for published in April 2012.

Correspondence address : Evi Yuliani, RS Permata Cibubur, Kota Wisata, Pesona Florence H1-28, Cibubur. Indonesia ; Email: eviyls@yahoo.co.id
Most of CTS patients are women within 30 to 80 year-old, with peak of incidence occurs at age of $60 .^{1-5}$

Clinical manifestations are pain, numbness and tingling sensation on the thumb, index finger, middle and an-half of fourth finger, which is commonly felt and awakens patients at night. ${ }^{6-8}$ Symptoms severity of CTS can be measured by using Symptom Severity Scale (SSS), a scale developed by Levine et.al 1993. Functional Status Scale (FSS) is used to measure functional status of patient with CTS. Both scale proved valid and reliable. ${ }^{9}$ Conservative treatment of CTS consists of pharmacological and nonpharmacological. Surgery management is done in advanced cases. Non-pharmacologicl management consists of wrist splint use, 
nerve and tendon gliding exercise, physical modalities, and modification of symptomrelated activities. .,10,11 Wrist splint is used in CTS on volar part to limit wrist motion and places the wrist at a neutral position by an angle of $0^{0}$ to reduce pressure on the carpal tunnel. ${ }^{8,11}$ Putting the splint on the neutral position due to biomechanic description that the pressure on carpal tunnel will be the least when wrist put at neutral position, flexion and extension of the wrist will be increasing pressure on that tunnel. ${ }^{12}$ Brininger at.al ( 2007) showed that a night splint resulted in significant improvement of SSS and FSS. Other result showed that using a neutral wristhand splint, hand refers to metacarpophalangeal (MCP) joint gave a greater improvement of perbaikan nilai SSS than cock-up wrist splint. ${ }^{13}$ Reasonable explanation describes that as the fingers actively flexed, particularly on MCP joint, lumbrical muscles get in the tunnel and increase the pressure. ${ }^{12,13}$ It is still unclear whether the MCP splint will give a better resu;t than a neutral wrist splint. Therefore, this study was conducted to compare effect of using both splint above which used at night, to SSS score dan FSS and to analyze validity and reliability of Indonesian version of SSS dan FSS. We surmise that using a wrist-MCP splint and exercise would be giving a better result in decreasing SSS and FSS scores than beutral wrist splint and exercise for CTS.

\section{METHODS}

This was a randomized controlled trial, pre and post. Subjects were divided randomizely into two trial groups. One was a neutral wrist splint and exercise (group A), the other was neutral wrist-MCP splint and exercise (group B). We conducted this trial at Physical Medicine and Rehabilitation Department, Hasan Sadikin Hospital Bandung. Number of sample was 19 in each group. Subjects were included to trial when meeting the criterias; idiopathic CTS refers to Rempel's , mild grade, female, 40 - 60 year-old, understand oral and written instruction, taking NSAID oral was washout for 2 weeks before trial. ${ }^{14,15}$ Subjects were exclude when having bilateral CTS, has history of CTS surgery, got steroid injection on fleksor retinakulum, got physical modalties therapy, thenar muscle atrophy, VAS $>7$. Subjects were dropped out when not able to exercise 3 times a day, and rejected to participate in study. Materials used in this study were assessment form including identity, history, physical examination, electrodiagnosis evaluation; logbook consists of persetujuan nerve and tendon glidingexercise, signed form of supervisor of splint use, diary of daily activities within 24 hours for 2 weeks. We used thermoplastic wrist splint int this study

We conducted a preliminary study of 20 subjects to have a valid and reliable Indonesian version of SSS and FSS. Test-retest methods

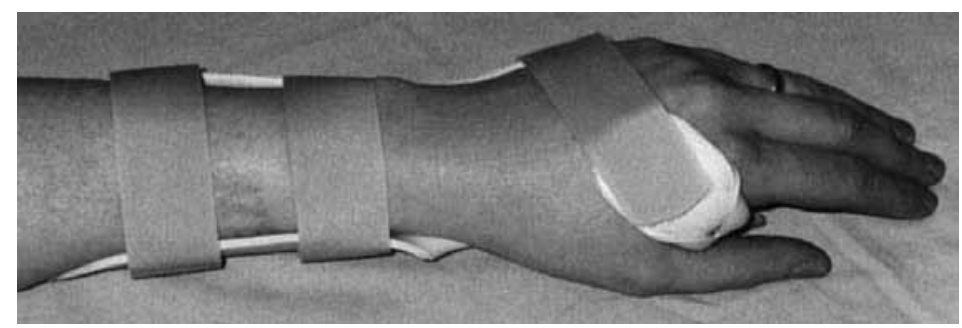

Figure 1 Neutral wrist splint. ${ }^{16}$

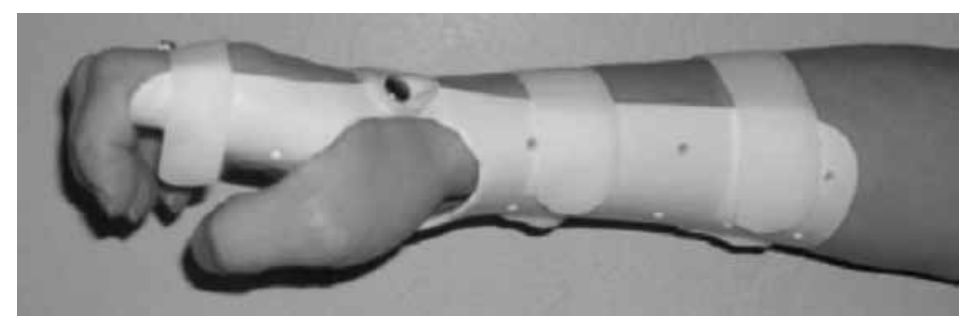

Figure 2. Neutral wrist - MCP splint. ${ }^{12}$ 
were used for repeated test in one hour distance and measured it with alfa Cronbach. Each item scores was correlated to the total score by using correlation coefficient rank Spearman to measure validity of those instruments. All randomized subjects in group A and B signed informed concent to participate in this study.

Subjects in both group were measured with SSS dan FSS in pre trial. Group A was using wrist splint with $0^{\circ}$ while group B using Wrist-MCP splint with angle $0^{\circ}$. Splint was used at night ( $\geq 6$ hours) everyday for 2 weeks. Both group conducted nerve and tendon gliding.exercise which was done consecutively in which every motion was held for 5 seconds and 10 times repeatedly. Exercise was done everyday, 5 times daily. All programs was recorded in logbook and signed by subjects and supervisor who living at the same house. Logbook was collected once a week for 2 weeks, along with the subject when he or she visited hospital for SSS, FSS and exercise technique evaluation.

Data was analized by using SPSS for Windows ver 13.0. We used Mann-Whitney to measure hyphotesis to compare effectivity on both groups. Significance of results was determined regarding $\mathrm{p}$ value $<0.05$.

Table 1. Validity of each item in SSS and FSS

\begin{tabular}{|c|c|c|c|c|c|}
\hline \multirow{2}{*}{ No. question } & \multicolumn{2}{|c|}{ SSS } & \multirow{2}{*}{$\begin{array}{c}\text { No. } \\
\text { question }\end{array}$} & \multicolumn{2}{|c|}{ FSS } \\
\hline & $\mathrm{r}_{\mathrm{s}}$ & $\mathrm{p}^{*)}$ & & $r_{s}$ & $\mathrm{p}^{*}$ \\
\hline $\mathrm{q}_{1}$ & 0.543 & 0.007 & $\mathrm{q} 12$ & 0.810 & 0.000 \\
\hline $\mathrm{q}_{2}$ & 0.513 & 0.011 & q13 & 0.530 & 0.008 \\
\hline $\mathrm{q}_{3}$ & 0.589 & 0.003 & q14 & 0.419 & 0.033 \\
\hline $\mathrm{q}_{4}$ & 0.402 & 0.040 & q15 & 0.467 & 0.019 \\
\hline $\mathrm{q}_{5}$ & 0.600 & 0.003 & q16 & 0.746 & 0.000 \\
\hline $\mathrm{q}_{6}$ & 0.515 & 0.010 & q17 & 0.769 & 0.000 \\
\hline $\mathrm{q}_{7}$ & 0.420 & 0.033 & q18 & 0.764 & 0.000 \\
\hline $\mathrm{q}_{8}$ & 0.512 & 0.011 & q19 & 0.490 & 0.014 \\
\hline $\mathrm{q}_{9}$ & 0.587 & 0.004 & & & \\
\hline $\mathrm{q}_{10}$ & 0.360 & 0.060 & & & \\
\hline $\mathrm{q}_{11}$ & 0.383 & 0.048 & & & \\
\hline
\end{tabular}

\section{RESULTS}

Preliminary trial for reliability of SSS and FSS showed Alpha-Cronbach for SSS 0.762 and FSS 0.781 that statictically significant $(>0.7)$, which means these instruments are reliable.

Tabel 1 shows the lowest rank Spearman coefficient correlation 0.360 and the highest 0.810 which is statistically significant $(>0.3)$, this result shows that those instruments are valid.

Table 2. SSS value on group $A$ and $B$

\begin{tabular}{cccc}
\hline SSS & $\mathrm{A}$ & $\mathrm{B}$ & \multirow{2}{*}{$(\mathrm{n}=19)$} \\
\hline Baseline & & & \\
Median & 2.55 & 2.45 & 0.357 \\
Range & $1.55-3.82$ & $1.27-4.00$ & \\
I (week I) & 1.36 & 1.55 & 0.373 \\
Median & $1.09-2.64$ & $1.09-2.55$ & \\
Range & & & 0.307 \\
II (week II) & 1.18 & 1.18 & \\
Median & $1.00-1.73$ & $1.00-1.82$ & \\
Range & &
\end{tabular}

*) p value was measured according to Mann-Whitney test,significance 0.05 . 
Characteristic of subjects showed that both group were not statistically different $\mathrm{p}>$ 0.05 according to age $(\mathrm{p}=1.000)$, education ( $\mathrm{p}$ $=0.707)$, activities $(\mathrm{p}=0.461)$, affected hand $(\mathrm{p}$
$=1.000)$, length of symptoms $(\mathrm{p}=0.977)$, and body mass index (BMI) $(\mathrm{p}=0.441)$.

Table 2 shows decrease of SSS on baseline (SSS I), second (SSS II) on both group. Baseline

Table 3. FSS value of group $A$ and $B$

\begin{tabular}{cccc}
\hline FSS & $\begin{array}{c}\mathrm{A} \\
(\mathrm{n}=19)\end{array}$ & $\begin{array}{c}\mathrm{B} \\
(\mathrm{n}=19)\end{array}$ & $\left.\mathrm{p}^{*}\right)$ \\
\hline Baseline & & & 0.352 \\
Median & 2.00 & 2.13 & \\
Range & $1.13-3.29$ & $1.29-4.00$ & 0.178 \\
$I$ (week I) & 1.43 & 1.29 & \\
Median & $1.00-2.12$ & $1.00-2.00$ & 0.036 \\
Range & 1.25 & 1.00 & \\
$I I$ (week II) & $1.00-1.57$ & $1.00-1.70$ & \\
Median & &
\end{tabular}

SSS on both group were $\mathrm{p}=0.357(\mathrm{p}>0.05)$ means no difference of baseline SSS on both group. The result of SSS I value was not statistically different between both group, $(\mathrm{p}=$
0.373; $p>0,05)$, neither did the SSS II of both group ( $\mathrm{p}=0.307 ; \mathrm{p}>0.05)$.

Table 3 shows decrease of FSS on baseline (FSS I) either on second (FSS II) on both group.

Table 4. Change of SSS value in each group

\begin{tabular}{lcccc}
\hline \multicolumn{1}{c}{ Change } & \multicolumn{3}{c}{$\mathrm{A}$} & $\mathrm{B}$ \\
\cline { 2 - 5 } SSS value & $\%$ & Nilai $\mathrm{p}^{*}$ & $\%$ & Nilai $^{*}$ \\
\hline Baseline $-\mathrm{I}$ & 46.67 & $<0.001$ & 36.73 & $<0.001$ \\
I - II & 13.24 & $<0.001$ & 23.87 & $<0.001$ \\
Baseline-II & 53.73 & $<0.001$ & 51.84 & $<0.001$ \\
\hline
\end{tabular}

*) p value was measured by Wilcoxon test,significance 0.05 .

Table 5. Change of FSS value in each group

\begin{tabular}{|c|c|c|c|c|}
\hline \multirow{2}{*}{$\begin{array}{l}\text { Change } \\
\text { FSS value }\end{array}$} & \multicolumn{2}{|c|}{ A } & \multicolumn{2}{|c|}{$\mathrm{B}$} \\
\hline & $\%$ & Nilai $p^{*}$ & $\%$ & Nilai $\left.p^{*}\right)$ \\
\hline Baseline $-\mathrm{I}$ & 28.50 & $<0.001$ & 39.44 & $<0.001$ \\
\hline $\mathrm{I}-\mathrm{II}$ & 12.59 & $<0.001$ & 22.48 & $<0.001$ \\
\hline Baseline -II & 37.50 & $<0.001$ & 53.05 & $<0.001$ \\
\hline
\end{tabular}

*) p value was measured by Wilcoxon test,significance 0.05 .

Baseline FSS value of both group was $\mathrm{p}=0.352$ $(\mathrm{p}>0.05)$ that means no significant different on both group.. FSS I value of both group was also not statistically different ( $\mathrm{p}=0.178 ; \mathrm{p}>0.05)$. Hasil FSS II value of both group, however, was significantly different $(\mathrm{p}=0.036 ; \mathrm{p}<0.05)$.

There was a significant decreased FSS ( $\mathrm{p}<$ 0.001; $\mathrm{p}<0.05$ ) between baseline FSS with FSS
I, baseline FSS with FSS II and FSS I with FSS II on both group.

\section{DISCUSSION}

Levine et.al showed a valid and reliable English version of SSS dan FSS to measure severity of CTS and ability of a CTS patient to 
do the activity of daily living.. ${ }^{9}$ To use those instruments in this study, we should translate them into an Indonesian version. Preliminary study conducted to 20 subjects found a valid and reliable instrument which then would be used to measure severity of CTS and functional status of subjects with CTS.

Characteristic of subjects included in both group was statistically not different which is a homogen group to compare. Subjects in this study were women because data shows that is CTS 4 to 5 times more occurred in women. In the United State,s $70 \%$ of CTS patients were women. This study limited the age of subjects from 40 to 60 year old refers to study that most of CTS patients aged $40-60$ year and peak incidence at $60 .^{2,18-20}$ The most common occupation in this study was housewife, was similar to Baysal et.al stated that an intensive use of hand by housewives plays important role in CTS incidence. ${ }^{21}$ CTS could be occurred unior bilateral in which a dominat hand is more likely affected. In this study, all subjects were right-handed and suffered CTS mostly on the right hand.1 Subejcts had been suffering CTS for 0,5 to 12 months. Burke et.al studied the use of splint on CTS patients who had been suffering CTS for $2 y$. They concluded that recovery of CTS was not related to the length of symptoms. ${ }^{22}$ Obesity is a risk factor for CTS, then obese subjects were excluded from this study, We referred to obesity's criteria of World Health Organization (WHO) BMI is $\geq 30 \mathrm{~kg} /$ $\mathrm{m}^{2} .23,24$

We included mild grade CTS on this study which had no thenar muscles. Muscle weakness indicates patients need a surgery intervention. ${ }^{15}$ A conservative treatment is choice of therapy for mild grade CTS. Conservative treatments given were wrist splint use and nerve and tendon gliding exercise which are treatment choices for mild CTS. ${ }^{12,16}$ Using a splint all day long will disturb activities and leads to low compliance of patients, therefore, regarding Walker et.al we determined a night splint use. ${ }^{15-16}$

There was a significant difference from baseline value to SSS I and SSS II in both groups, respectively similar to study of Burke et.al. This study along with Burke's suppoet other study that stated that splint use will give improvement maximally in 2 to 3 weeks... ${ }^{1,26,27}$ Gravlee and Durme stated that more decreasing symptoms occurred in using neutral wrist splint than with a cock up splint with $20^{\circ}$ of wrist extension and decreased symptoms occurred in 2 first weeks of splint use. $^{28}$

This result support the theory that the least pressure to carpal tunnel gained on neutral position of wrist as $0^{\circ}$ so that decrease pressure on median nerve on the tunnel. Using a wrist splint based on this theory will be decrease symptoms of CTS. ${ }^{12,16,21}$ Gelbermen et.al found that pressure on the tunnel at neutral position of wrist was $32 \mathrm{mmHg}$, at $90^{\circ}$ flexion was 94 $\mathrm{mmHg}$, and $90^{\circ}$ of extension was $110 \mathrm{mmHg}$. Tunnel's pressure on healty subjects was 2,5 $\mathrm{mmHg}$ at neutral position, $31 \mathrm{mmHg}$ at flexion and $30 \mathrm{mmHg}$ at extension. ${ }^{29}$

Improvement on group B supports the theory above and by limited MCP flexion, it prevents the lumbrical muscles entering the tunnel so that pressure in the tunnel would not be increased. ${ }^{13,18}$ Brininger et.al found that neutral wrist-MCP splint had more improved SSS value than cock up wrist splint. ${ }^{12}$

A nerve and tendon gliding exercise is able to stretch and detach in the tunnel, widening the contact area between median nerve with transversal carpal ligament, reducing tenosunovial edema, improve blood supply of median nerve and reduce pressure in the tunnel. Seradge et.al measured the pressure in the tunnel in vivo and found that regular active motion exercise of wrist and fingers for one minute had decreased the pressure in it. Alkalin et.al found a greater improvement in subjects who used neutral wrist splint and did nerve and tendon gliding exercise compared to them who only used a neutral wrist splint. ${ }^{30-32}$

We found insignificant difference of SSS I between group A and B. This might be caused by a same program which were splint and exercise though a different splint. Previous studies showed wrist splint and exercise had already given a good improvement, therefore, a Wrist-MCP splint would not be a big difference. A study using neutral wrist- MCP splint by Brininger et.al compared neutral wrist-MCP splint to cock up wrist splint found that WristMCP splint gave a better improvement of 
SSS. ${ }^{12}$ That study supports theory above that $20^{\circ}$ of wrist extension causes increased tunnel's pressure.

This study found an improvement of FSS from baseline to week I, week I to II and from baseline to week II on both groups. This improvement of functional staus occurred in both groups. Elicited symptoms will affect the activity of daily living in patients. A decrease of symptoms measured by SSS will improve functional status of patients which was measured by FSS. This result states that the more severe CTS, the worse functional status of patients with CTS. It is can be assumed that FSS value is inversely to the SSS value that was proved by correlation test.

That the result of FSS I value in both groups was not significantly different might be related to insignificant improvement of SSS value in both groups. From FSS II, however, we found a significant difference between both groups in which B had a greater improvement. This result supports the hypothesis that neutral wrist-MCP splint will give more improvement than a wrist splint.

Use of SSS and FSS as measurement was not sufficient and so limits this study. We suggest to use nerve conduction velocity electodiagnosis as one of measurement to evaluate improvement more objectively. Besides that, we could not observe directly the use of night splint although we had given direction to use splint at least 6 hours at night, this then could lower the accuracy to evaluate subject's compliance.

\section{CONCLUSIONS}

SSS and FSS are valid and reliable instruments to measure severity of CTS and functional status for CTS patients. Both neutral Wrist splint and exercise and neutral Wrist-MCP splint and exercise give significant improvement of SSS and FSS on both group. There was a clinically difference of SSS between booth groups but it was not statistically. The group of Wrist-MCP splint and exercise gave better result and statistically difference of FSS II than the other group.

Based on these results we recommend to use Wrist-MCP splint in neutral position in clinical practice for mild CTS. We suggest to a further study that uses regular NCV electrodiagnosis to measure objectively the improvement of splint use as described above. It is suggested to test the correlation between SSS and FSS, and also by homogenizing the occupation of subjects may reduce limitation of low compliance.

\section{REFERENCES}

1. Zhao M, Burke D. Median neuropathy. In: Frontera WR, Silver JK, Rizzo TD, editor. Essentials of physical medicine and rehabilitation. 2nd edition. Philadelphia: Saunders Elsevier; 2008.p.173-7.

2. Seffinger MA, Hruby RJ. Carpal Tunnel Syndrome. In: Evidence Based Manual Medicine A Problem Oriented Approach. Philadelphia: Saunders Elsevier; 2007.p. 273-89.

3. Nadler SF, Schuler S, Nadler JS. Cumulative trauma disorders. In: Delisa JA, editor. Physical medicine \& rehabilitation: principles and practice. 4th edition. Philadelphia: Lippincott Williams \& Wilkins; 2005.p.615-24.

4. Hartanto H. Kamus kedokteran Dorland. 29th edition. Jakarta: EGC; 2005.

5. Misbach HJ, Hamid AB, Mayza A, Saleh MK, editor. Buku pedoman standar pelayanan medis dan standar prosedur operasional neurologi. Jakarta: PERDOSSI; 2006

6. Cailliet R. Hand pain and impairment. Philadelphia: FA Davis Company; 1975.

7. Boongird P. Compression and entrapment neuropathies. Thailand: Swicharn Press; 1996.

8. Hertling D, Kessler RM. Wrist and hand complex. In:Hertling D,et al. Management of common musculoskeletal disorder. 4th edition. Philadelphia: Lippincott Williams and Wilkins; 2006.p. 415-6.

9. Levine DW, Simmons BP, Koris MJ, Daltroy LH, Hohl GG, Fossel AH, Katz JN. A self administered questionnaire for the assessment of severity of symptoms and functional status in Carpal Tunnel Syndrome. J Bone Joint Surg Am. 1993; 75A(11): 1585-92.

10. Keith A, Bengtson KA, Brault JS. Hand disorders. In: Delisa JA, editor. Physical 
medicine \& rehabilitation: principles and practice. 4th editor Philadelphia: Lippincott Williams \& Wilkins; 2005.p. 843-4.

11. Mark A, Thomas MA, Felsenthal G, Fast A, Young M. Peripheral neuropathy. In: Delisa JA, editor. Physical medicine \& rehabilitation: principles and practice. 4th edition. Philadelphia: Lippincott Williams \& Wilkins; 2005.p. 903-4.

12. Brininger MAJTL, Rogers JC, Holm MB, Baker NA, Li ZM, Goitz RJ. Efficacy of a fabricated customized splint and tendon and nerve gliding exercises for the treatment of Carpal Tunnel Syndrome: a randomized controlled trial. Arch Phys Med Rehabil. 2007; 88: 1429-35.

13. Joshi SD, Joshi SS, Athavale SA. Lumbrical muscles and carpal tunnel. J Anat Soc India. 2005; 54: 12-5.

14. Rempel D, Evanoff B. Consensus criteria for the clasification of Carpal Tunnel Syndrome. American Journal of Public Health. 1998; 88(10): 1447-51.

15. Brotzman SB. Carpal Tunnel Syndrome. In: Brotzman SB, Wilk KE, editor. Handbook of orthopaedic rehabilitation. 2nd edition. Philadelphia: Mosby Elsevier; 2007.p.52-67.

16. Walker WC, Metzler M, Cifu DX, Swartz Z. Neutral Wrist Splinting in Carpal Tunnel Syndrome: A Comparison of Night-Only Versus Full-TimeWear Instructions. Arch Phys Med Rehabil. 2000;81:424-9.

17. Setiaji B. Modul 15 Uji Validitas Dan Reliabilitas. In: Panduan Riset Dengan Pendekatan Kuantitatif. 2004. cited August 30, 2010. http://eprints.ums. ac.id/911/.

18. Connoly WB, McKessar JM. Carpal Tunnel Syndrome can it be a work related condition? Australian Family Physician. 2009; 38: 684-6.

19. Rallo D, Frank C. Carpal Tunnel Management Eases Syndrome Discomfort. Biomechanics. 2008; 15: 517.

20. Hertling D. Soft Tissue Manipulation. In:Hertling D Management of common musculoskeletal disorder (4th ed).
Philadelphia: Lippincott Williams and Wilkins; 2006.p. 227-32.

21. Baysal O, Altay Z, Ozcan C, Ertem K, Yologlu S, Kayhan A. Comparison of Three Conservative Treatment Protocols in Carpal Tunnel Syndrome. Int J Clin Pract. 2006; 60: 820-8.

22. Kisner C, Colby LA. Therapeutic exercise foundations and techniques 4th edition. Philadelphia: FA Davis Company; 2002.

23. Peterson A, Kincaid JC. Rehabilitation of patients with neuropathies. In: Braddom RL, editor. Physical medicine and rehabilitation. 3rd edition. China: Saunders Elsevier; 2007.p. 1079-80.

24. Halls SB. Overweight Definition Using Body Mass Index. 2008. cited August 7, 2010. http://www.hall.md/body-massindex/overweight.htm.

25. Premoselli S, Sioli P, Grossi A, Cerri C. Neutral wrist splinting in Carpal Tunnel Syndrome : a 3- and 6-month clinical and neurophysiologic follow-up evaluation of night only splint therapy. Eura Medicophys. 2006; 42: 121-6.

26. Huistede BM, Hoogvliet P, Randsdorp MS, Glerum S, Middelkoop M, Koes BW. Carpal Tunnel Syndrome. Part 1: Effectiveness of Nonsurgical Treatments - A Systematic Review. Arch Phys Med Rehabil. 2010; 291: 981-1004.

27. Piazzini DB dkk. A Systematic Review of Conservative Treatment of Carpal Tunnel Syndrome. Clinical Rehabilitation. 2007; 21: 299-314.

28. Gravlee JR, Durme DJ. Braces And Splints For Musculoskeletal Condition. American Family Physician. 2007; 75: 342-8.

29. Kostopoulo D. Treatment of Carpal Tunnel Syndrome: a Review of The NonSurgical Approaches With Emphasis in Neural Mobilization. Journal of Bodywork and Movement Therapies. 2004; 8: 2-8.

30. Michlovitz SL. Conservative interventions for Carpal Tunnel Syndrome. Journal of Orthopaedic and Sport Physical Therapy. 2004; 34(10): 589-600.

31. Alkalin E dkk. Treatment of Carpal Tunnel Syndrome with Nerve and 


\section{TM PT.TRSSA MANDRRIMEDTITHINDO General Supplier \& Services}

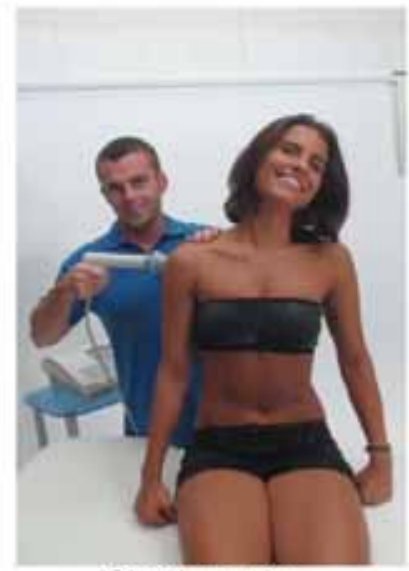

Shock-waves

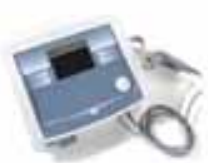

Ultrasound Therapy

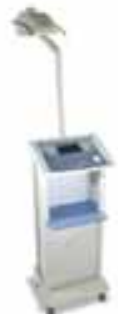

Scanning laser

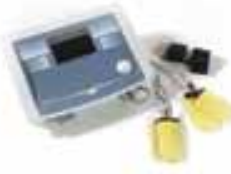

Electrotherapy

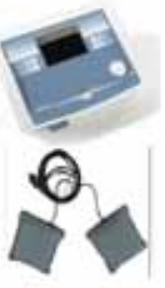

magnetic therapy

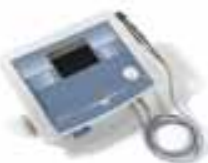

Laser Therapy

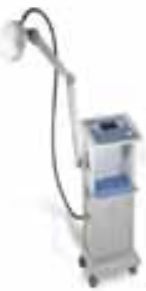

Microwave diathermy

Physiotherapy and Rehabilitation Equipment

Combimed therapy Parallel bars

PT. Trisna Mandiri Meditalindo is general supplier and service for physiotherapy and medical rehabilitation equipment.

PTTrisna Mandiri Meditalindo as a distributor for EME, Theraband, Heuser, Metron, Chinesport, Medical device and Bauerfeind.

Magnetic therapy

Traction unit

2 Paraflin bath

Trting table

Infrared lamp

$$
\begin{aligned}
& \text { Quadriceps bench } \\
& \text { Pulley } \\
& \text { Theraband product } \\
& \text { Wall bars } \\
& \text { Etc. }
\end{aligned}
$$

